[Type text]

\title{
Science and conservation of Amazonian crocodilians: a historical review
}

Boris Marioni ${ }^{1}$, José António L. Barão-Nóbrega ${ }^{2}$, Robinson Botero-Arias ${ }^{3}$, Fábio Muniz ${ }^{4}$, Zilca Campos ${ }^{5}$, Ronis Da Silveira ${ }^{6}$, William E. Magnusson ${ }^{7}$, Francisco Villamarín ${ }^{8}$

1 Pós-Graduação em Biologia de Água Doce e Pesca Interior - Instituto Nacional de Pesquisas da Amazónia (Manaus - AM, Brazil);

2 School of Science, Engineering and Environment - University of Salford (Greater Manchester, UK);

${ }^{3}$ Department of Wildlife Ecology and Conservation - Institute of Food and Agricultural Sciences, University of Florida (Gainesville - FL, USA);

${ }^{4}$ Laboratório de Evolução e Genética Animal - Universidade Federal do Amazonas (Manaus - AM, Brazil);

${ }^{5}$ Laboratório de Vida Selvagem - Embrapa Pantanal (Corumbá - MS, Brazil);

${ }^{6}$ Laboratório de Manejo de Fauna, Instituto de Ciências Biológicas, Universidade Federal do Amazonas (Manaus - AM, Brazil);

${ }^{7}$ Coordenação de Biodiversidade - Instituto Nacional de Pesquisas da Amazónia (Manaus AM, Brazil);

${ }^{8}$ Grupo de Biogeografía y Ecología Espacial BioGeoE2, Universidad Regional Amazónica Ikiam (Tena - Napo, Ecuador).

\section{Abstract}

2 1. Crocodilians represent one of the oldest extant vertebrate lineages. They have co-existed 3 with humans throughout the Amazon basin for thousands of years, often having a strong 4 cultural and economic influence on people's lives. Shifts in the socio-economic and political 5 reality of the Amazon basin during the last century have led crocodilian populations to face 


\section{[Type text]}

6 large variations in their numbers according to different levels of exploitation and strategies

7 for their conservation.

8 2. This article reviews the scientific knowledge on the biology and conservation/management

9 produced between 1945 and 2019 for the four Amazonian crocodilian (caiman) species

10 (Caiman crocodilus, Melanosuchus niger, Paleosuchus palpebrosus and Paleosuchus

11 trigonatus). We provide a general overview on past and current population status and

12 research efforts involving caimans in the Amazon basin and discuss perspectives for the

13 future.

14 3. The most significant studies relating to the ecology, genetics and management strategies

15 are examined in more detail and this information is contextualized to provide an overview of

16 the most relevant findings that might explain caiman population trends over the last 75 years.

17 4. Sustainable-management systems in the Amazon basin have been discussed for the past 20

18 years, but remain rarely applicable. It is necessary to develop new ways to maintain healthy

19 caiman populations through innovative management programs. Sustainable harvesting of

20 wildlife has been shown to leverage conservation targets, especially those initiatives based on

21 community co-management. Herein, we propose some general guidelines for future

22 management schemes, with great expectation that, differently from past experiences, the

23 information provided by the scientific community is fully considered and political agendas do

24 not determine the priorities.

25 Keywords: Wetland, Floodplain, Protected Area, Sustainability, Monitoring, Reptiles, $26 \quad$ Fishing

\section{1. Introduction}




\section{[Type text]}

28 Caimans (Crocodylia, Alligatoridae) have co-existed with humans throughout the Amazon 29 basin for more than 6,000 years, often having a strong influence on people's lives. Although riverine people respect these large vertebrates, opinion of the general public is generally negative regarding caimans, especially those inhabiting areas in close proximity to human settlements. Despite low human population densities (3-4 inhabitants $\left./ \mathrm{km}^{2}\right)$ in the Amazon region $(\mathrm{FAO}, 2016)$ and the relatively low incidence of attacks on people (Haddad Jr \& Fonseca, 2011; Pooley, 2018), conflicts have augmented as caiman populations have steadily increased in size during the last four decades, especially in Central Amazonia.

The Amazon basin covers approximately 700 million hectares (Venticinque et al., 2016), mostly belonging to Brazil (68\%), but also distributed in Peru (13\%), Bolivia (10\%), Colombia (4\%), Ecuador (2\%), Venezuela (1\%), Guyana (1\%) and Suriname (1\%). The Amazon is mainly composed of non-flooded forests and several types of wetlands associated with highly dynamic hydrological systems influenced by annual flooding (Junk, Piedade, Wittmann, Schöngart, \& Parolin, 2010). This heterogeneous spatial distribution of aquatic ecosystems sustains four sympatric crocodilian species (Figure 1): Spectacled caiman (Caiman crocodilus crocodilus), Black caiman (Melanosuchus niger), Cuvier's Dwarf caiman (Paleosuchus palpebrosus) and Schneider's Dwarf caiman (Paleosuchus trigonatus), as well as hybrids between $C$. c. crocodilus and Caiman crocodilus yacare (Hrbek, Vasconcelos, Rebelo, \& Farias, 2008). Caiman c. yacare is often considered a separate species (Busack \& 47 Sima, 2001; Roberto et al., 2020), but almost all the literature to date has considered all individuals of Caiman in the Amazon basin to belong to the species $C$. crocodilus, and in the absence of consistent characteristics to distinguish the two postulated species in the wild or in the literature we treat all Amazonian crocodilians in the genus Caiman as C. crocodilus in 51 this review. Melanosuchus niger and C. crocodilus are the largest species and are usually 


\section{[Type text]}

52 more abundant in floodplain areas where the majority of human settlements are located (Da

53 Silveira, 2002; Da Silveira, Magnusson, \& Thorbjarnarson, 2008).

54 Until the 1970's, most studies on South American crocodilians were still focused on 55 morphology, nomenclature (Medem, 1958) and zoogeography (Sill, 1968), and the first 56 attempts to speculate on ecological relationships between caimans and their environment were drafted by Fittkau (1970). As occurred with many crocodilian species worldwide, Amazonian caimans were hunted for their valuable skins with no constraints. As a result, many wild populations experienced severe reductions, some becoming scarce and others were considered nearly extinct (Grigg \& Kirshner, 2015). The ban on hunting and commercialization of caiman products resulted in a progressive recovery of caiman populations (Thorbjarnarson, 1999). This was also a consequence of the creation of multiple protected areas in the region (Tavares de Freitas et al., 2019). Currently, threats to

64 crocodilians in the Amazon basin are mainly associated with habitat loss, increased pollution, 65 dam construction, expansion of agriculture and uncontrolled urban growth (Campos, 2015; 66 Campos, 2019). Today, Amazonian caimans are being killed to serve as bait to capture the scavenger fish Calophysus macropterus. Although local people do not consume this catfish, its commercialization provides a source of income and sustenance to fisher families (BoteroArias, Franco, \& Marmontel, 2014; Brum, da Silva, Rossoni, \& Castello, 2015; Da Silveira \& 70 Viana, 2003).

71 Worldwide studies on natural history, ecology and conservation status of crocodilians have resulted in a significant recent increase in available literature, with $25 \%$ of studies being carried out after 2007 (Grigg \& Kirshner, 2015). This information has contributed to the

74 elaboration of conservation action plans and is the basis for designing management 75 initiatives. The general aim of this review is to summarize scientific knowledge relating to conservation and management of the four Amazonian crocodilian species within the Amazon 


\section{[Type text]}

77 basin. Based on this general overview of current research and perspectives for the future, we

78 address five questions: (1) How has scientific knowledge on crocodilians evolved in the

79 Amazon basin? (2) How were caiman populations impacted by past commercial exploitation?

80 (3) What ecological attributes may explain caiman resilience to hunting? (4) Is there evidence

81 on the viability of management of wild populations in the Amazon? and (5) What are the

82 main gaps that should be addressed for future research and conservation efforts?

\section{2. Methods}

84 We have carried out a literature review using the online search engine Web of Science 85 (www.webofscience.com) up to December 2019 in order to evaluate the scientific literature 86 on the four caiman species occurring in the Amazon basin. The decision to use this database 87 was based on its clarity when returning results to the query, its detailed citation-analysis tools 88 (Falagas, Pitsouni, Malietzis, \& Pappas, 2008) and the opportunity to exclude grey literature 89 (summary reports, congress presentations and unpublished dissertations) when summarizing 90 information. Undoubtedly, the latter type of publications contains important information, but 91 not being peer-reviewed makes it difficult to evaluate their scientific strengths and flaws. 92 Furthermore, this information is not always readily available. We limited our search to the 93 75-year period between 1945 and 2019 using the scientific names of the four target caiman 94 species. This query returned general information on the overall scientific production related 95 to these four alligatorids. We considered the total raw number of results obtained by the 96 search algorithm and further discuss the information from studies produced on caiman 97 ecology and conservation in the Amazon basin.

\section{Results and Discussion}




\section{[Type text]}

100 The search query returned a total of 439 publications on the four Amazon species, excluding 101 studies on Caiman crocodilus subspecies (C. crocodilus fuscus and C. c. chiapascus), which 102 do not occur in the Amazon basin (Roberto et al., 2020). Of these, 65\% corresponded to $C$. 103 crocodilus, $20 \%$ to $M$. niger (84), $8 \%$ to P. palpebrosus (36) and $7 \%$ to P. trigonatus (33). 104 Over the entire 75-year period, search results indicated 51 years with at least one publication 105 on one of the Amazon caiman species, with annual numbers varying from 1 to 34 106 publications (mean $=9.2 \pm 8.4$ ). The most frequently studied species was $C$. crocodilus with 107 a maximum of 20 studies per year (a mean of 5.6 studies/year amongst 50 years with at least 108 one publication on the species). For the other three species the mean publication rate was 3.2 109 studies per year for M. niger (26 years), mean of two studies per year for P. palpebrosus (18 110 years) and a mean of 1.5 studies per year for P. trigonatus (21 years). More than $70 \%$ of 111 publications on $M$. niger and $P$. palpebrosus were produced after 2010 . Only $15 \%$ of scientific studies with Paleosuchus species were published before 2000. These results suggest that general scientific knowledge gathered on Amazonian crocodilians is growing

114 consistently. Brazil limits encompass the largest portion of Amazon basin; in consequence 115 the great majority of studies discussed here were carried out in this country, also origin of most of scientists implied or funding agencies responsible for such studies.

117 Commercial exploitation of Amazonian crocodilians: from steady declines to thriving 118 populations

119 During the first decades of the past century, the Amazon basin experienced a very prosperous but short period of rubber extraction and when this period ended abruptly riverine people 121 turned to selling hides of local fauna to supply North American and European markets 122 (Antunes et al., 2016). Unfortunately, there is limited information on the status of caiman 123 populations before the commercial exploitation of skins in the twentieth century. One of the 124 first relevant studies noted that caiman eggs sold at very low prices might have had a negative 


\section{[Type text]}

125 effect on population numbers, though caimans were still very abundant in the region (Reese,

126 1923). Between 1940 and 1950, different caiman products were legally commercialized by

127 the cosmetic and leather industries (Pereira, 1944) and this period corresponded to the peak

128 of skin commerce in the Amazon (Antunes et al., 2016). The widespread commercial

129 exploitation of caimans that extended until the mid-1970s affected caiman populations

130 throughout the entire basin.

131 Unregulated commerce took place for decades and no attempts were made to control

132 harvesting areas, target species, body size of harvested individuals or hunting seasons. None

133 of the supplier countries developed their own manufacturing industries or promoted internal

134 markets. During most of the $20^{\text {th }}$ century, both $M$. niger and $C$. crocodilus were heavily

135 hunted for their skins, which resulted in sharp declines of wild populations throughout their

136 distribution. There is no evidence that the two species of Paleosuchus were ever hunted

137 sufficiently to drastically affect their densities (Da Silveira, 2003). Thus, subsequent

138 discussion of caiman hunting will only address $M$. niger and C. crocodilus.

139 In 1975, in response to increasing concerns that the unregulated trade could result in

140 biological extinction, international agencies and individual countries regulated global

141 commerce as a means to protect wild crocodilians by ratifying the Convention on

142 International Trade in Endangered Species (CITES). Amazonian countries (Brazil, Ecuador

143 and Peru in 1975; Venezuela in 1977; Bolivia in 1979 and Colombia in 1981) ratified the

144 CITES convention and put into place a new defensive (for fauna) and restrictive (for humans)

145 legislation. Complementary to the creation of several protected areas, killing or trade of wild

146 species was now considered a crime in most countries and transgressors risked facing high

147 fines or even jail sentences. However, although international commerce was officially

148 restricted, demand for skins was still high (Inskipp \& Wells, 1979), and legal loopholes

149 allowed for trade of stockpiled skins acquired prior to the new legislation. This facilitated on- 


\section{[Type text]}

150 going illegal hunting for at least ten years after the international ban (Antunes et al., 2016;

151 Rebêlo \& Magnusson, 1983), until the market became economically unviable and eventually

152 faded (Da Silveira, 2002).

153 The first scientific studies documenting aspects of crocodilian past commercial exploitation

154 were undertaken only after the ban on international commerce of wild fauna. Based on

155 number of skins traded, the wild stocks exploited commercially must have been massive at

156 the beginning of the activity. Medem (1981) estimated that at least 11 million skins were

157 exported from Colombia and reported species depletion in several parts of South America

158 (Medem, 1983). More than seven million caiman skins were legally exported from Amazonas

159 State (Brazil) within a 15-year period and the number of skins exported from Peru drastically 160 decreased between 1960 and 1970 (Smith, 1981).

161 In the early 1980s, M. niger was thought to be on the brink of extinction throughout its 162 distribution, mainly due to overhunting to supply the leather industry (Best, 1984; Plotkin, 163 Medem, Mittermeier, \& Constable, 1983; Vanzolini \& Gomes, 1979). It was suggested that 164 this large-bodied species is less resistant to hunting than the sympatric C. crocodilus, mainly 165 because females need a longer period of time to attain sexual maturity (Magnusson \& Rebêlo, 166 1983). Almost 30 years later, another study based on numbers of exported skins confirmed 167 that $M$. niger is one of the least-resilient species to commercial exploitation amongst the 168 many Amazonian vertebrates that were historically commercialized (Antunes et al., 2016). 169 Apparently, differences in habitat use among caiman species influence their resilience to 170 hunting pressure (Magnusson, 1986). Caimans occurring in lakes and rivers, such as some 171 populations of $M$. niger, were more easily available and heavily affected by hunting than 172 species living in swamps or savannahs where accessibility to the entire population was more 173 challenging. Some initiatives to recover M. niger populations started during the 1990s. In 174 Bolivia, the first re-introduction of M. niger was carried out in 1990, when 25 captive sub- 


\section{[Type text]}

175 adults (6 males and 19 females) were released (Pacheco, Aparicio, \& Thorbjarnarson, 1991).

176 Subsequently, it was reported that 8 to 10 individuals of this group remained residents at the

177 release location and later reproduced (Pacheco, 1995).

178 More than two decades after the ban on commercial hunting for skins, caiman populations

179 were thriving in most of the Amazon basin. However, a new threat was reported in the 1990s

180 in Brazil. Caimans were killed for their meat while their undervalued skins were discarded in

181 the river. This was a result of a huge regional market of dry-salted meat with more than 8000

182 individuals killed annually in just one area, which represented approximately 100 tons/year

183 sold illegally to markets in Colombia and the Brazilian State of Para (Da Silveira \&

184 Thorbjarnarson, 1999). There were no detailed studies regarding caiman population status as

185 a function of meat commerce in other countries, although illegal traffic in caiman meat is still

186 frequently found in some Peruvian and Colombian markets (Kirkland et al., 2018; van Vliet

187 et al., 2014) despite wildlife trade being illegal in these countries since 1973 (Smith, 1981).

188 In spite of the ongoing trade in meat, it has been suggested that where habitat loss was not a 189 significant factor, the reduction of commercial hunting for skins allowed many crocodilian 190 populations to recover (Thorbjarnarson, 1999). Populations hunted for meat had very high 191 densities in some regions (especially Brazil) and it was suggested that this new form of use

192 based on a source-sink system could be sustainable because it targeted mainly sub-adult 193 males away from reproduction areas (Da Silveira \& Thorbjarnarson, 1999). Furthermore, 194 since accessibility to some isolated water bodies is greatly reduced during the dry season in 195 the Amazon, harvesting success is strongly affected by water level and hunting effort 196 (Mendonça, Marioni, Thorbjarnarson, Magnusson, \& Da Silveira, 2016). Lack of access to 197 refrigeration combined to high volume and mass of harvested meat hampers poachers from 198 exploiting isolated areas, which are normally preferred nesting sites for $M$. niger 199 (Thorbjarnarson \& Da Silveira, 2000; Villamarín et al., 2011). Consequently, if well planned, 


\section{[Type text]}

200 meat harvesting of wild Amazonian crocodilian populations has been suggested to be both

201 biologically and economically sustainable as it can target individuals of specific size/sex and

202 has the potential to become a source of income for riverine people (Da Silveira \&

203 Thorbjarnarson, 1999; Thorbjarnarson, 1999).

\section{Genetics and ecology of caiman populations}

205 Scientific studies over the last 40 years have increased our knowledge on caiman biology, 206 and herein we present a short summary of scientific studies that contribute to understand 207 resilience of caiman species to overhunting. After decades of overexploitation, studies on the 208 genetic structure of populations showed that heavy commerce of skins during the past century 209 had no detectable effect on the genetic diversity of the two most hunted species in the 210 Amazon (Farias et al., 2004; Glenn et al., 2002; Vasconcelos et al., 2006).

211 These species suffered a similar decline in population densities as the American alligator 212 (Alligator mississippiensis), considered today the most rebounded crocodilian species in the 213 world. It has been hypothesized that higher genetic diversity may confer resilience to species 214 (Green et al., 2014; Souza-Filho et al., 2018; Willi \& Hoffmann, 2009) and studies based on 215 cytochrome b data have shown that $M$. niger and $C$. crocodilus are genetically more diverse 216 than A. mississippiensis (Farias et al., 2004; Glenn et al., 2002; Muniz et al., 2018; 217 Vasconcelos et al., 2006). This observation suggests some resilience of both Amazonian 218 species to population declines.

219 One of the mechanisms that facilitate the resilience of crocodilian populations to overhunting 220 might be found in their mating system. Multiple paternity increases effective population size 221 by maintaining genetic variation, and therefore acting as an important mechanism to preserve 222 genetic diversity in isolated local populations (Chesser \& Baker, 1996; Muniz et al., 2011; 223 Rafajlović et al., 2013). Polyandry might be beneficial to females as it increases the genetic 


\section{[Type text]}

224 variability of their offspring (Yasui, 1998). Multiple paternity has been detected in both species subjected to heavy hunting in the Amazon basin (Muniz et al., 2011; Oliveira, Farias, Marioni, Campos, \& Hrbek, 2010; Oliveira, Marioni, Farias, \& Hrbek, 2014).

227 The population resilience of Amazonian caimans can further be associated to ecological 228 strategies contributing to avoid competitive exclusion and have allowed the co-existence of 229 all four species. Differences in diet among caiman species have been assessed (Da Silveira \& Magnusson, 1999; Magnusson, da Silva, \& Lima, 1987) and there is evidence that suggest that some species consume more terrestrial prey than others while occupying the same water body (Villamarín, Jardine, Bunn, Marioni, \& Magnusson, 2017). Furthermore, larger species generally do not influence the feeding behaviour of smaller ones (Marioni, Da Silveira, Magnusson, \& Thorbjarnarson, 2008).

235 Nesting ecology might also be an important factor influencing the persistence of caiman 236 populations. Although reproduction in crocodilians is usually characterized by very high 237 mortality rates at early stages (Somaweera, Brien, \& Shine, 2013), parental care and nest-site selection might increase survival rates and facilitate population growth. Mortality of crocodilian eggs and hatchlings is generally caused by nest predation or flooding, and this applies to Amazonian species (Thorbjarnarson, 1996; Villamarín \& Suárez, 2007). A

241 relatively wide range of caiman nest predators has been identified in the Amazon basin 242 (Barão-Nóbrega et al., 2014; Campos \& Mourão, 2014; Campos, Muniz, Desbiez, \& 243 Magnusson, 2016; Villamarín \& Suárez, 2007), However, there is evidence that in some 244 species the presence of attending females may reduce egg predation (Barão-Nóbrega et al., 245 2014; Campos \& Sanaiotti, 2006; Torralvo, Botero-Arias, \& Magnusson, 2017) and increase 246 hatchling survival (Campos, Sanaiotti, Muniz, Farias, \& Magnusson, 2012). Some studies 247 indicate that nest-site selection may contribute to decreased egg mortality. M. niger females seem to prefer water bodies isolated from the early annual rising of water level and thus, the 


\section{[Type text]}

249 probability of nest flooding is greatly reduced (Thorbjarnarson \& Da Silveira, 2000;

250 Villamarín et al., 2011). A different nesting strategy is shown by females of the sympatric $C$.

251 crocodilus, which often build their nests far from permanent water bodies where floods take

252 longer to arrive (Thorbjarnarson \& Da Silveira, 2000; Villamarín et al., 2011).

253 Crocodilian females have low mortality rates and relatively long life spans (Somaweera et al., 254 2013) and larger females lay more eggs (Campos, Magnusson, Sanaiotti, \& Coutinho, 2008; 255 Campos, Mourão, Coutinho, \& Magnusson, 2014; Campos, Sanaiotti, Marques, \& 256 Magnusson, 2015) despite important metabolic costs (Barão-Nóbrega et al., 2017). Under 257 ideal natural conditions, individual females may have many successful reproductive events 258 throughout their lifespan (Gienger et al., 2017).

259 All these biological and ecological features provide insights to explain the capacity of 260 crocodilians to maintain numerous populations and recover from over exploitation once 261 commercial hunting ended.

262 Drifting from total protection to sustainable-management initiatives of wild caiman 263 populations

264 The information on genetics and ecology of Amazon caimans gathered during the last three 265 decades suggests the feasibility of science-based sustainable-management programs. 266 Worldwide, crocodilian management programs have been carried out in more than 40 267 countries since the late 1980s (Thorbjarnarson, 1992). Management programs based entirely 268 on the sale of wildlife skins have shown their limitations related to the instability of luxury 269 markets (Thorbjarnarson, 1999). Thus, possibilities to diversify into meat production should 270 be examined, adding value particularly in local markets where harvesting is taking place, as is 271 the case in Venezuela (Thorbjarnarson \& Velasco, 1999). In Louisiana for example, the sale 272 of alligator meat and skins reached 25 million USD per year in the early 1990s (Joanen, 


\section{[Type text]}

273 McNease, Elsey, \& Staton, 1997).

274 Many successful management programs are based on "ranching" systems where wild-caught

275 eggs or hatchlings are raised in captivity and a fraction of them are released back to the wild

276 (Campos, Mourão, Coutinho, Magnusson, \& Soriano, 2015; Thorbjarnarson, 1999). These

277 programs have provided evidence of the importance of stakeholder involvement in South

278 America, especially in Argentina (Gelabert, Rositano, \& González, 2017). Ranching systems

279 are of potential conservation importance, and often involve releasing schemes (Hutton \&

280 Webb, 2003; Jenkins, Jelden, Webb, \& Manolis, 2004), though the effectiveness of these has

281 not been rigorously evaluated. Nevertheless, high costs associated with infrastructure, animal

282 feeding and correct slaughter conditions turn ranching economically unfeasible in most

283 Amazonian localities. Only two ranching initiatives are known to have taken place in the

284 Amazon basin, one near Manaus in Brazil and the other in Ecuador. Both were financially

285 unsuccessful and collapsed (Thorbjarnarson, 1994; Velasco, 2008; Verdade, 2004).

286 Captive breeding programs (farming) have proved to be biologically viable and economically 287 effective in many countries worldwide (Adan, 2000; Tosun, 2013). However, as is the case of 288 ranching programs, the amount of investment needed would be a limiting factor in the 289 Amazon context, added to the fact that local inhabitants would be excluded from such 290 initiatives (Thorbjarnarson, 1999). It is important to emphasize though that legal management 291 programs may not be exempt of drawbacks and some have even been used as a way to 292 launder illegal commerce (Miranda Montero, Khan, \& Wright, 2019; van Uhm \& Nijman, 293 2020). Between 2005 and 2010, illegal trade in C. crocodilus skins may have doubled the 294 amount legally declared by countries, indicating a high frequency of poaching despite 295 increasingly restrictive laws (Balaguera-Reina \& Densmore III, 2014; Da Silveira, Gordo, 296 Marcon, \& Silva, 1998; Webb \& Jenkins, 2016). 


\section{[Type text]}

297 Given the large extent of the Amazon basin and the high densities of caiman populations in

298 some localities, extensive harvesting of wild individuals seems more appropriate, especially

299 because of its lower operational costs and high conservation value for the environment (Da

300 Silveira, 2011; Thorbjarnarson, 1999; Verdade, 2004). It has been proposed that protecting

301 nesting sites (Da Silveira \& Thorbjarnarson, 1999; Thorbjarnarson \& Da Silveira, 2000;

302 Villamarín et al., 2011) and establishing an upper size limit (Campos et al., 2008) would 303 contribute to maintain viable populations on a long-term management basis, avoiding

304 females, which have a smaller size. To this end, geographic information systems and remote 305 sensing coupled with field nest-surveys are useful tools to identify nesting sites at large306 scales and may guide management activities (Banon, Arraut, et al., 2019; Banon, Banon, et 307 al., 2019; Da Silveira \& Thorbjarnarson, 1999; Villamarín et al., 2011).

308 In general, Brazilian legislation prohibits harvesting and commercialization of wildlife. 309 However, it allows trade of a restricted number of species under strictly developed 310 management plans within sustainable-development protected areas (Brazilian Government, 311 2011). This has permitted the commercialization of fish species that are protected in other 312 areas, such as Arapaima spp., which has leveraged their population recovery and improved 313 the income of local people (Campos-Silva \& Peres, 2016). Such successful experiences 314 (Castello, Stewart, \& Arantes, 2011; Castello, Viana, Watkins, Pinedo-Vasquez, \& Luzadis, 315 2009) could become working models to achieve sustainability in wild-harvest caiman 316 management programs.

317 An experimental wild harvest and subsequent commercial initiative were carried out in the 318 Brazilian mid-Solimões River (Brazilian upper Amazon) between 2004 and 2008. This was 319 made possible by the downlisting of $M$. niger populations to CITES Appendix II, with the 320 endorsement of the IUCN/SSC Crocodile Specialist Group in June 2007 (CITES, 2007). The main scope of this initiative was to generate technical procedures for the production of meat 


\section{[Type text]}

322 and skins in central Amazonian floodplains (Botero-Arias, Marmontel, \& de Queiroz, 2009).

323 After more than 550 adult $M$. niger were killed in three different experimental harvesting

324 events, the main lesson learned was that the management of crocodilians in the Brazilian

325 Amazon was, at that time, still economically unsustainable. Activities were planned under a

326 government agenda, using wrong extrapolations of population parameters and monitoring

327 that violate basic principles of wildlife management (Da Silveira, 2011).

328 However, one of the main reasons why wild harvesting of Amazonian caimans has not

329 succeeded is that, unlike other countries with legal meat harvesting programs of crocodilian

330 species, the federal Ministry of Agriculture in Brazil required caimans to be slaughtered

331 under the same conditions as cattle, rather than Arapaima in Brazil or fish in general. This is

332 especially problematic given that most of the human population in the Amazon basin does not

333 have access to electricity or even clear water. Strong limitations on logistical conditions

334 increase time from capture to slaughter and most likely raise costs. These are all issues to be

335 overcome in order to achieve sustainability in any management initiative with Amazonian

336 caimans.

337 At the regional level, local legislation for wildlife management is different from country to 338 country. Except for a community-based management program in Bolivia (Aparicio \& Rios, 339 2006), management activities of wild populations in the Amazon basin are still in their 340 experimental phase and are being carried out only in Brazil (Table 1). Other management 341 initiatives, such as captive-breeding farms in Colombia (Velasco, 2008; Webb, Brien,

342 Manolis, \& Medrano-Bitar, 2012) are focused on C. c. fuscus, a sub-species not occurring in 343 the Amazon basin. In Venezuela, all successful harvesting experiences carried out between

3441990 and 2015 were conducted on C. crocodilus populations from the Orinoco river basin

345 (Thorbjarnarson \& Velasco, 1999; Velasco, 2008). Despite the wide extent of the Amazon 


\section{[Type text]}

346 basin and the occurrence of high-density caiman populations, we are not aware of any further

347 management initiatives currently being undertaken.

\section{Perspectives for caiman conservation in the Amazon basin}

349 In the present days, Amazonian caiman species exhibit stable populations throughout much 350 of their distribution range (but see Ortiz, Dueñas, Villamarín, \& Ron, 2020) and all four 351 species are listed as Least-Concern in IUCN Red Lists (Balaguera-Reina \& Velasco, 2019; 352 Campos, Magnusson, \& Muniz, 2019; Magnusson, Campos, \& Muniz, 2019; Perran Ross, 353 2000). Populations of $P$. trigonatus and $P$. palpebrosus are generally not affected by 354 commercial hunting, though they may be affected by dam construction, roads (Campos, 355 Magnusson, \& Muniz, 2012; Campos, Mourão, \& Magnusson, 2017) and other local effects 356 of human activities such as subsistence hunting, which is particularly heavy on these species 357 (Campos \& Muniz, 2019; Da Silveira, 2003; Lugo, Lasso, Castro, \& Morales-Betancourt, 358 2013). However, it is possible that some of the recently described evolutionary units (Muniz 359 et al., 2018) have low effective population sizes, and in consequence lower resilience to long360 term conservation threats. This indicates the importance of monitoring population genetic 361 parameters of newly discovered lineages.

362 It is difficult to generalize about the Amazon basin, which covers an area similar to those of 363 Australia or continental USA, but scientific research has revealed consistent trends. The first 364 ecological information was generated for $M$. niger populations only at the end of the past century. In Brazil and Bolivia, some studies aimed at understanding how environmental variables (air/water temperature, water depth, percentage illumination by the moon and cloud

367 cover) influence the number of caimans detected during night surveys (Da Silveira, 368 Magnusson, \& Campos, 1997; Pacheco, 1996). This information was useful for the 


\section{[Type text]}

370 based on night surveys should be taken cautiously because the results obtained from one

371 locality can not be extrapolated to the entire Amazon basin (Da Silveira et al., 2008).

372 Sustainable harvesting of wildlife in the Amazon has been shown to leverage conservation

373 targets, especially those initiatives based on community co-management (Bodmer \& Puertas,

374 2000; Campos-Silva \& Peres, 2016; Castello et al., 2009; Mattos Vieira, von Muhlen, \&

375 Shepard, 2015) where all stakeholders are considered as part of the solution (Marioni,

376 Botero-Arias, \& Fonseca-Junior, 2013). After the ban on international commerce of

377 crocodilian skins, total protection was the only reasonable choice of local governments to

378 protect South American crocodilians. It was based on one basic rule: no hunting or commerce

379 of any wildlife product anytime or anywhere. However, it is necessary to develop new ways

380 to maintain healthy caiman populations while simultaneously alleviating poverty levels in

381 local communities through innovative management programs.

382 Sustainable-management systems have been discussed for the past 20 years but remain only a

383 theoretical idea rarely applicable to the Amazonian reality. Fixed protocols and "cookbook

384 recipes" do not take into account the complexity of local environments and are often hard to

385 implement in different regions or countries. We have developed some general guidelines,

386 principally based on our experiences. First, monitoring of caiman populations must be

387 regularly carried out on a long-term basis by trained local people and under the guidance of

388 independent scientists. The main aim will be to supervise population trends and eventually

389 estimate annual quotas. Second, strictly protected zones based on nest-site preferences within

390 protected areas must be delineated with the involvement of local inhabitants, researchers and

391 regional authorities. Reproduction areas have to be considered to build solid bases for a

392 source-sink system (Brawn \& Robinson, 1996; Da Silveira, 2011; Da Silveira \&

393 Thorbjarnarson, 1999) and a clear zonation allows to avoid harvesting adult females. Third, 394 economic business plans must be elaborated to estimate the potential market of targeted 


\section{[Type text]}

395 products (meat, skins, etc.), as without a strong economic feasibility, the management 396 program will not be viable. Consequently, community-based management projects must be 397 designed to become economically independent over the mid-term period. Financial 398 dependence on regional politicians or private donors will most likely hinder management

399 programs in the long term. However, government funding as initial economic support is very 400 important to assess population status, to carry out early-stage population studies, to establish 401 the first harvest quotas by surveying population trends, to train local people in the different 402 phases of the project and to build the logistic infrastructure necessary to initiate the activity.

403 More than 10 years after the last attempt, a new harvesting program for wild $M$. niger and $C$.

404 crocodilus is being proposed for 2020 within a protected area in the central Brazilian 405 Amazon. In this region, local communities have a broad experience in managing aquatic 406 natural resources and it is also where one of the highest $M$. niger and $C$. crocodilus densities 407 have been reported (Castello, Viana, \& Pinedo-Vasquez, 2011). At least two distinct market 408 plans will be proposed: meat, targeted towards regional and national consumers, and skins, 409 which should be sold internationally. This new initiative was planned and strongly supported 410 economically by local governments from the outset, which makes it difficult to replicate such

411 experience in other localities without similar economic support, development time and 412 expertise from everyone involved. There is great expectation that, contrary to previous 413 endeavours, the information provided by the scientific community is considered in full and 414 that political agendas do not determine the priorities. The past experience should be 415 fundamental to implement harvesting protocols already developed on a long-term and large416 scale perspective in order to improve standard procedures for capture, slaughter and 417 commercialization of caiman products.

418 For modern commercial exploitation of Amazonian crocodilians, an important challenge will 419 be to develop markets for raw or manufactured products. Regional markets have not shown 


\section{[Type text]}

420 great demand for caiman-meat, except in a few high-priced restaurants and supermarkets.

421 Furthermore, although caiman skins have their place in the market, alligator and crocodile

422 skins are considered "classic" leathers due to the scarcity of osteoderms (Fuchs \& Schepp,

423 2006); as such South American caiman skins are sold for lower prices (IUCN-SSC Crocodile

424 Specialist Group, 2019; Louisiana Alligator Advisory Council, 2019). Thus, the greatest

425 challenge will be to maintain a sustainable production chain from local hunters to urban

426 consumers.

427 Because management strategies need to be designed according to the characteristics of each

428 region (Rodriguez-Cordero, Balaguera-Reina, \& Densmore III, 2019) and taking into

429 consideration environmental conditions and land ownership, there is still high demand for

430 further scientific studies on caiman population trends across most of their distribution

431 throughout the Amazon. Overall knowledge on the four Amazonian caiman species has

432 significantly increased in Brazil during the last decade, but it is still incipient in many other

433 countries, where few scientific studies are targeting these species. Although more research is

434 necessary to understand the impacts of habitat loss and urban area expansion, past experience

435 has shown that science alone is not enough; local communities and government agencies

436 have to be involved in order to develop systems that are socially, economically and

437 ecologically viable. Traditionally, when not enough biological and social information is

438 available, politicians tend to rule out all decisions. At the present time however, the scientific

439 community has produced a vast amount of knowledge that will provide valuable input on the

440 all stages of the process. Effective actions toward sustainable management of wild caiman

441 populations must then consider the best options to integrate economic return to local

442 inhabitants, habitat preservation and species conservation.

\section{Acknowledgements}




\section{[Type text]}

444 The authors would like to acknowledge all scientists, students and field assistants responsible

445 for the research carried on caimans in Amazon floodplains over the years. Without their

446 effort, our knowledge on crocodilians would still be incomplete. We also want to

447 acknowledge all environmental enforcement authorities, financial agencies and communal

448 councils responsible for issuing permits and providing financial and logistic support, which

449 enabled the on-going research in different countries. BM received a Ph.D. scholarship from

450 the National Council for Scientific and Technological Development (CNPq -Brazil). WEM

451 was supported by the CNPq and the Program for Biodiversity Research (PPBio-AmOc) and

452 the National Institute for Amazonian Biodiversity (INCT-CENBAM). We thank Leandro

453 Castello for providing useful recommendations on previous versions of the manuscript and

454 Dr Perran Ross (University of Florida) and Dr Matthew Shirley (Florida International

455 University) for their critical suggestions on a previous version of the manuscript. We are

456 immensely grateful to John Thorbjarnarson (in memoriam) for all his huge expertise, precious

457 advises and great happiness toward crocodilian science, especially Amazon caimans.

458

459 References

460

461

462

463

464

465

466

467

Adan, R. I. Y. (2000). Crocodile farming: a multi-million dollar industry. SEAFDEC Asian Aquaculture, 22, 22-28.

Antunes, A. P., Fewster, R. M., Venticinque, E. M., Peres, C. A., Levi, T., Rohe, F., \& Shepard, G. H. (2016). Empty forest or empty rivers? A century of commercial hunting in Amazonia. Science Advances, 2, e1600936.

Aparicio, J., \& Rios, J. (2006). Experiencias de manejo en el proceso de aprovechamiento sostenible del lagarto (Caiman yacare) en Bolivia (1995-2004). Revista Electrónica de Manejo de Fauna Silvestre en Latinoamérica, 1, 1-11. 


\section{[Type text]}

468 Balaguera-Reina, S. A., \& Densmore III, L. D. (2014). Legislation and conservation efforts concerning crocodiles in Colombia: a historical review. Herpetological Review, 45, 638-642.

Balaguera-Reina, S. A., \& Velasco, A. (2019). Caiman crocodilus. The IUCN Red List of Threatened Species, e.T46584A11062106.

Banon, G. P. R., Arraut, E. M., Villamarín, F., Marioni, B., Moulatlet, G. M., Rennó, C. D., ... Novo, E. (2019). A review on crocodilian nesting habitats and their characterisation via remote sensing. Amphibia-Reptilia, 40, 1-21.

Banon, G. P. R., Banon, G. J. F., Villamarín, F., Arraut, E. M., Moulatlet, G. M., Rennó, C. D., ... Novo, E. M. L. D. M. (2019). Predicting suitable nesting sites for the Black caiman (Melanosuchus niger Spix 1825) in the Central Amazon basin. Neotropical Biodiversity, 5, 47-59.

Barão-Nóbrega, J. A. L., Marioni, B., Botero-Arias, R., Nogueira, A. J. A., Lima, E. S., Magnusson, W. E., ... Marcon, J. L. (2017). The metabolic cost of nesting: body condition and blood parameters of Caiman crocodilus and Melanosuchus niger in Central Amazonia. Journal of Comparative Physiology B, 188, 127-140.

Barão-Nóbrega, J. A. L., Marioni, B., Villamarín, F., Soares, A. M. V. M., Magnusson, W. 485 E., \& Da Silveira, R. (2014). Researcher disturbance has minimal impact on natural predation of caiman nests in Central Amazonia. Journal of Herpetology, 48, 338-342.

Best, R. C. (1984). The aquatic mammals and reptiles of the Amazon. In: H. Sioli (Ed.) The Amazon. Monographiae Biologicae. (pp. 371-412), Dordrecht: Springer.

Bodmer, R. E., \& Puertas, P. E. (2000). Community-based comanagement of wildlife in the 490 Peruvian Amazon. In: J. G. Robinson, \& E. L. Bennett (Eds.), Hunting for sustainability in tropical forests. (pp. 395-409), New York: Columbia University Press. 


\section{[Type text]}

493 Botero-Arias, R., Franco, D. L., \& Marmontel, M. (2014). A mortalidade de jacarés e botos associada à pesca da piracatinga na região do Médio Solimões-Amazonas, Brasil. Tefé - Amazonas, Brasil: Instituto de Desenvolvimento Sustentável Mamirauá.

Botero-Arias, R., Marmontel, M., \& de Queiroz, H. L. (2009). Projeto de manejo experimental de jacarés no Estado do Amazonas: abate de jacarés no setor JarauáReserva de Desenvolvimento Sustentável Mamirauá, Dezembro de 2008. UAKARI, 5, 49-57.

Brawn, J. D., \& Robinson, S. K. (1996). Source-sink population dynamics may complicate the interpretation of long-term census data. Ecology, 77, 3-12.

502 Brazilian Government (2011). Lei $\mathrm{n}^{\mathrm{o}}$ 9.985, de 18 de julho de 2000; Decreto $\mathrm{n}^{\mathrm{o}}$ 4.340, de 22 de agosto de 2002; Decreto $\mathrm{n}^{\circ}$ 5.746, de 5 de abril de 2006. Plano Estratégico Nacional de Áreas Protegidas: Decreto no 5.758, de 13 de abril de 2006. Brasilia: Ministério do Meio Ambiente - Sistema Nacional de Unidades de Conservação da Natureza (SNUC).

Brum, S. M., da Silva, V. M. F., Rossoni, F., \& Castello, L. (2015). Use of dolphins and 508 caimans as bait for Calophysus macropterus (Lichtenstein, 1819) (Siluriforme: Pimelodidae) in the Amazon. Journal of Applied Ichthyology, 31, 675-680.

510 Busack, S. D., \& Sima, P. (2001). Geographic variation in Caiman crocodilus and Caiman yacare (Crocodylia: Alligatoridae): Systematic and legal implications. Herpetologica, 57, 294-312.

513 Campos-Silva, J. V., \& Peres, C. A. (2016). Community-based management induces rapid recovery of a high-value tropical freshwater fishery. Scientific Reports, 6, 34745.

515 Campos, Z. (2015). Size of caimans killed by humans at a hydroelectric dam in the Madeira River, Brazilian Amazon. Herpetozoa, 28, 101-104. 


\section{[Type text]}

517 Campos, Z. (2019). Disruption of reproductive behaviour of black caiman, Melanosuchus niger in the Santo Antônio hydroeletric dam, Madeira River, Brazilian Amazon. The Herpetological Bulletin, 148, 26-28.

520 Campos, Z., Magnusson, W. E., \& Muniz, F. (2012). Dead Paleosuchus on roads in Brazil. IUCN/SSC Crocodile Specialist Group Newsletter, 31, 12-12.

522 Campos, Z., Magnusson, W. E., \& Muniz, F. L. (2019). Paleosuchus trigonatus. The IUCN 523 Red List of Threatened Species, e.T46588A3010035.

524 Campos, Z., Magnusson, W. E., Sanaiotti, T. M., \& Coutinho, M. (2008). Reproductive 525 trade-offs in Caiman crocodilus crocodilus and Caiman crocodilus yacare: implications for size-related management quotas. Herpetological Journal, 18, 91-96.

Campos, Z., \& Mourão, G. (2014). Camera traps capture images of predators of Caiman 528 crocodilus yacare eggs (Reptilia: Crocodylia) in Brazil's Pantanal wetlands. Journal of Natural History, 49, 977-982.

530 Campos, Z., Mourão, G., Coutinho, M., \& Magnusson, W. E. (2014). Growth of Caiman crocodilus yacare in the Brazilian Pantanal. PloS ONE, 9, e89363.

532 Campos, Z., Mourão, G., Coutinho, M., Magnusson, W. E., \& Soriano, B. M. A. (2015). Spatial and temporal variation in reproduction of a generalist crocodilian, Caiman crocodilus yacare, in a seasonally flooded wetland. PLoS ONE, 10, e0129368.

535 Campos, Z., Mourão, G., \& Magnusson, W. E. (2017). The effect of dam construction on the movement of dwarf caimans, Paleosuchus trigonatus and Paleosuchus palpebrosus, in Brazilian Amazonia. PloS ONE, 12, e0188508.

538 Campos, Z., \& Muniz, F. L. (2019). Multiple uses of Cuvier`s Dwarf caimans, Paleosuchus palpebrosus, in the Semi-arid region of northeastern, Brazil IUCN/SSC Crocodile Specialist Group Newsletter, 38, 5-8. 


\section{[Type text]}

541 Campos, Z., Muniz, F. L., Desbiez, A. L. J., \& Magnusson, W. E. (2016). Predation on eggs of Schneider's dwarf caiman, Paleosuchus trigonatus (Schneider, 1807), by armadillos and other predators. Journal of Natural History, 50, 1543-1548.

544 Campos, Z., \& Sanaiotti, T. (2006). Paleosuchus palpebrosus. Nesting. Herpetological Review, 37, 81-81.

546 Campos, Z., Sanaiotti, T., Marques, V., \& Magnusson, W. E. (2015). Geographic variation in clutch size and reproductive season of the dwarf caiman, Paleosuchus palpebrosus, in Brazil. Journal of Herpetology, 49, 95-98.

549 Campos, Z., Sanaiotti, T. M., Muniz, F. L., Farias, I., \& Magnusson, W. E. (2012). Parental care in the dwarf caiman, Paleosuchus palpebrosus Cuvier, 1807 (Reptilia: Crocodilia: Alligatoridae). Journal of Natural History, 46, 2979-2984.

552 Castello, L., Stewart, D. J., \& Arantes, C. C. (2011). Modeling population dynamics and 553 conservation of arapaima in the Amazon. Reviews in Fish Biology and Fisheries, 21,

555 Castello, L., Viana, J. P., \& Pinedo-Vasquez, M. (2011). Participatory conservation and local knowledge in the Amazon várzea: the pirarucu management scheme in Mamirauá. In: M. Pinedo-Vasquez, M. Ruffino, C. Padoch, \& E. Brondízio (Eds.), The Amazon Várzea. (pp. 259-273), Dordrecht: Springer.

559 Castello, L., Viana, J. P., Watkins, G., Pinedo-Vasquez, M., \& Luzadis, V. A. (2009). Lessons from Integrating Fishers of Arapaima in Small-Scale Fisheries Management at the Mamirauá Reserve, Amazon. Environmental Management, 43, 197-209.

562 Chesser, R. K., \& Baker, R. J. (1996). Effective sizes and dynamics of uniparentally and 563 diparentally inherited genes. Genetics, 144, 1225-1235.

564 CITES. (2007). Convention on International Trade in Endangered Species of Wild Fauna and 565 Flora. CoP14 Prop. 13. Considerations of Proposal for Amendment of Appendices I 
[Type text]

566

567

568

569

570

571

572

573

574

575

576

577

578

579

580

581

582

583

584

585

586

587

588

589

590

and II. Conference of the Parties. The Hague (Netherlands), 3-15 June 2007. Available: $\quad \underline{\text { http://www.cites.org/eng/cop/14/prop/E14-P13.pdf }}$ [Accessed 20 November 2019].

Da Silveira, R. (2002). Conservação e manejo do jacaré-açu (Melanosuchus niger) na Amazônia Brasileira. La Conservación y el Manejo de Caimanes y Cocodrilos de América Latina, 2, 61-78.

Da Silveira, R. (2003). Avaliação preliminar da distribuição, abundância e da caça de jacarés no baixo Rio Purus. In: C. Pereira de Deus, R. Da Silveira, \& L. H. Rapp Py-Daniel (Eds.), Piagaçu-Purus: Bases científicas para a criação de uma Reserva de Desenvolvimento Sustentável. (pp. 61-64), Manaus, Brazil: Instituto de Desenvolvimento Sustentável Mamirauá.

Da Silveira, R. (2011). Management of wildlife in the floodplain: a critical look at threats, bottlenecks, and the future in Amazonia. In: M. Pinedo-Vasquez, M. Ruffino, C. Padoch, \& E. Brondízio (Eds.), The Amazon Várzea. (pp. 137-144), Dordrecht: Springer.

Da Silveira, R., Gordo, M., Marcon, J. L., \& Silva, J. R. (1998). Skins from wild Spectacled caiman confiscated in the Amazonia. IUCN/SSC Crocodile Specialist Group Newsletter, 17, 7-8.

Da Silveira, R., \& Magnusson, W. E. (1999). Diets of spectacled and black caiman in the Anavilhanas Archipelago, Central Amazonia, Brazil. Journal of Herpetology, 33, $181-192$.

Da Silveira, R., Magnusson, W. E., \& Campos, Z. (1997). Monitoring the distribution, abundance and breeding areas of Caiman crocodilus crocodilus and Melanosuchus niger in the Anavilhanas Archipelago, Central Amazonia, Brazil. Journal of Herpetology, 31, 514-520. 


\section{[Type text]}

591 Da Silveira, R., Magnusson, W. E., \& Thorbjarnarson, J. B. (2008). Factors affecting the number of caimans seen during spotlight surveys in the Mamirauá Reserve, Brazilian Amazonia. Copeia, 2008, 425-430.

594 Da Silveira, R., \& Thorbjarnarson, J. B. (1999). Conservation implications of commercial hunting of black and spectacled caiman in the Mamirauá Sustainable Development Reserve, Brazil. Biological Conservation, 88, 103-109.

Da Silveira, R., \& Viana, J. P. (2003). Amazonian crocodilians: A keystone species for ecology and management... Or simply bait? IUCN/SSC Crocodile Specialist Group Newsletter, 22(1), 16-17.

600 Falagas, M. E., Pitsouni, E. I., Malietzis, G. A., \& Pappas, G. (2008). Comparison of 601

602 PubMed, Scopus, web of science, and Google scholar: strengths and weaknesses. The FASEB journal, 22, 338-342.

FAO. (2016). Amazon Basin. Food and Agriculture Organization of the United States (FAO). Available: http://www.fao.org/nr/water/aquastat/basins/amazon/index.stm [Accessed 17 November 2019].

Farias, I. P., Da Silveira, R., de Thoisy, B., Monjeló, L. A., Thorbjarnarson, J., \& Hrbek, T. 607 (2004). Genetic diversity and population structure of Amazonian crocodilians. Animal Conservation, 7, 265-272.

Fittkau, E. J. (1970). Role of caimans in the nutrient regime of mouth-lakes of Amazon affluents (an hypothesis). Biotropica, 2, 138-142.

Fuchs, K., \& Schepp, U. (2006). The crocodile skin: Important characteristics in identifying

\section{3} crocodilian species Frankfurt: Edition Chimaira.

614

Gelabert, C., Rositano, F., \& González, O. (2017). Sustainable use of caiman in Argentina: An analysis from the perspective of the stakeholders involved. Biological Conservation, 212, 357-365. 


\section{[Type text]}

616 Gienger, C. M., Brien, M. L., Tracy, C. R., Manolis, S. C., Webb, G. J. W., Seymour, R. S., \& Christian, K. A. (2017). Ontogenetic comparisons of standard metabolism in three species of crocodilians. PloS ONE, 12, e0171082.

619 Glenn, T. C., Staton, J. L., Vu, A. T., Davis, L. M., Bremer, J. R. A., Rhodes, W. E., ... Sawyer, R. H. (2002). Low mitochondrial DNA variation among American alligators and a novel non-coding region in crocodilians. Journal of Experimental Zoology, 294, $312-324$.

Green, R. E., Braun, E. L., Armstrong, J., Earl, D., Nguyen, N., Hickey, G., ... Castoe, T. A. (2014). Three crocodilian genomes reveal ancestral patterns of evolution among archosaurs. Science, 346, 1254449.

Grigg, G., \& Kirshner, D. (2015). Biology and evolution of crocodylians Australia: Csiro Publishing.

Haddad Jr, V., \& Fonseca, W. C. (2011). A fatal attack on a child by a black caiman (Melanosuchus niger). Wilderness \& Environmental Medicine, 22, 62-64.

630 Hrbek, T., Vasconcelos, W. R., Rebelo, G., \& Farias, I. P. (2008). Phylogenetic relationships of South American Alligatorids and the Caiman of Madeira River. Journal of Experimental Zoology Part A: Ecological Genetics and Physiology, 309A, 588-599.

Hutton, J. M., \& Webb, G. (2003). Crocodiles: legal trade snaps back. In: S. Oldfield (Ed.) The trade in wildlife: Regulation for conservation. (pp. 108-114), London: Earthscan Publications Ltd.

636 Inskipp, T., \& Wells, S. (1979). The International Wildlife Trade. London: International 637 Institute for Environment and Developent and the Fauna Preservation Society. 


\section{[Type text]}

641 Jenkins, R. W., Jelden, D., Webb, G. J., \& Manolis, S. C. (2004). Review of crocodile ranching programmes. Conducted for CITES by the Crocodile Specialist Group of IUCN/SSC.

644 Joanen, T., McNease, L., Elsey, R., \& Staton, M. (1997). The commercial consumptive use of

645

646

647

648

649

650

651

652

653

654

655

656

657

658

659

660

661

662

663

664

665 the American alligator (Alligator mississippiensis) in Louisiana: its effects on conservation. In: C. H. Freese (Ed.) Harvesting Wild Species. (pp. 465-506), Baltimore, Maryland: The John Hopkins University Press.

Junk, W. J., Piedade, M. T. F., Wittmann, F., Schöngart, J., \& Parolin, P. (2010). Amazonian floodplain forests: Ecophysiology, Biodiversity and Sustainable Management Heidelberg, Germany: Ecological Studies, Springer.

Kirkland, M., Eisenberg, C., Bicerra, A., Bodmer, R. E., Mayor, P., \& Axmacher, J. C. (2018). Sustainable wildlife extraction and the impacts of socio-economic change among the Kukama-Kukamilla people of the Pacaya-Samiria National Reserve, Peru. Oryx, 1-10.

Louisiana Alligator Advisory Council. (2019). Distinguishing features of crocodilian leathers [Online]. Available: https://www.louisianaalligators.com/crocodilian-leatherfeatures.html [Accessed 15 December 2019].

Lugo, M., Lasso, C. A., Castro, A., \& Morales-Betancourt, M. A. (2013). Paleosuchus trigonatus (Schneider 1801). In: M. A. Morales-Betancourt, C. A. Lasso, J. De La Ossa, \& A. Fajardo-Patiño (Eds.), Biología y Conservación de los Crocodylia de Colombia - Serie Recursos Hidrobiolgógicos y Pesqueros Continentales de Colombia. (pp. 201-210), Bogotá, D. C., Colombia: Instituto de Investigación de Recursos Biológicos Alexander von Humboldt (IAvH).

Magnusson, W. E. (1986). The peculiarities of crocodilian population dynamics and their possible importance for management strategies. 7th Working Meeting of the 
[Type text]

666

667

668

669

670

671

672

673

674

675

676

677

678

679

680

681

682

683

684

685

686

687

688

689

690

UICN/SSC Crocodile Specialist Group. Quito, Ecuador: IUCN-The World Conservation Union, Gland, Switzerland.

Magnusson, W. E., Campos, Z., \& Muniz, F. L. (2019). Paleosuchus palpebrosus. The IUCN Red List of Threatened Species, e.T46587A3009946.

Magnusson, W. E., da Silva, E. V., \& Lima, A. P. (1987). Diets of Amazonian crocodilians. Journal of Herpetology, 21, 85-95.

Magnusson, W. E., \& Rebêlo, G. H. (1983). Brazilian crocodiles: problems of conservation in a multi-species system. Zimbabwe Science News, 17, 56-57.

Marioni, B., Botero-Arias, R., \& Fonseca-Junior, S. F. (2013). Local community involvement as a basis for sustainable crocodilian management in protected areas of Central Amazonia: Problem or solution? Tropical Conservation Science, 6, 484-492.

Marioni, B., Da Silveira, R., Magnusson, W. E., \& Thorbjarnarson, J. (2008). Feeding behavior of two sympatric caiman species, Melanosuchus niger and Caiman crocodilus, in the Brazilian Amazon. Journal of Herpetology, 42, 768-773.

Mattos Vieira, M. A., von Muhlen, E. M., \& Shepard, G. H. (2015). Participatory Monitoring and Management of Subsistence Hunting in the Piagaçu-Purus Reserve, Brazil. Conservation Society, 15, 254-264.

Medem, F. (1958). The crocodilian genus Paleosuchus. Fieldiana: Zoology, 39, 227-247.

Medem, F. (1981). Los Crocodylia de sur América Bogotá, Colombia: Ministerio de Educación Nacional, Fondo Colombiano de Investigaciones Científicas y Proyectos Especiales.

Medem, F. (1983). Los Crocodylia de sur América Bogotá, Colombia: Colciencias.

Mendonça, W. C. D. S., Marioni, B., Thorbjarnarson, J. B., Magnusson, W. E., \& Da Silveira, R. (2016). Caiman hunting in Central Amazonia, Brazil. The Journal of Wildlife Management, 80, 1497-1502. 


\section{[Type text]}

691 Miranda Montero, J. J., Khan, M. N., \& Wright, E. M. (2019). Illegal logging, fishing, and wildlife trade: The costs and how to combat it. Washington, D.C.: World Bank Group.

Muniz, F. L., Campos, Z., Rangel, S. M. H., Martínez, J. G., Souza, B. C., De Thoisy, B., ... Farias, I. P. (2018). Delimitation of evolutionary units in Cuvier's dwarf caiman, Paleosuchus palpebrosus (Cuvier, 1807): insights from conservation of a broadly distributed species. Conservation Genetics, 19, 599-610.

Muniz, F. L., Da Silveira, R., Campos, Z., Magnusson, W. E., Hrbek, T., \& Farias, I. P. (2011). Multiple paternity in the black caiman (Melanosuchus niger) population in the Anavilhanas National Park, Brazilian Amazonia. Amphibia-Reptilia, 32, 428-434.

Oliveira, D. P., Farias, I. P., Marioni, B., Campos, Z., \& Hrbek, T. (2010). Microsatellite 701

702 markers for mating system and population analyses of the spectacled caiman Caiman crocodilus (Linnaeus 1758). Conservation Genetics Resources, 2, 181-184.

703

704

Oliveira, D. P., Marioni, B., Farias, I., \& Hrbek, T. (2014). Genetic evidence for polygamy as 705 a mating strategy in Caiman crocodilus. Journal of Heredity, 105, 485-492.

Pacheco, L. F. (1995). Black caiman breeding in Normandia lagoon. IUCN/SSC Crocodile 706 Specialist Group Newsletter, 14, 12-17.

707 Pacheco, L. F. (1996). Effects of environmental variables on black caiman counts in Bolivia. 708 Wildlife Society Bulletin, 24, 44-49.

709 Pacheco, L. F., Aparicio, J., \& Thorbjarnarson, J. B. (1991). The first reintroduction of black caiman, Melanosuchus niger, into the wild. Herpetological Review, 22, 90-91.

711 Pereira, N. (1944). A utilização da carne do jacaré na Amazônia. Boletim Geográfico Rio de Janeiro, 2, 150-152.

713 Perran Ross, J. (2000). Melanosuchus niger. The IUCN Red List of Threatened Species, e.T13053A3407604. 


\section{[Type text]}

715 Plotkin, M. J., Medem, F., Mittermeier, R. A., \& Constable, I. D. (1983). Distribution and conservation of the black caiman (Melanosuchus niger). Advances in Herpetology and Evolutionary Biology, 695-705.

718 Pooley, S. (2018). Croc digest: a bibliography of human-crocodile conflict research and reports (2nd Edition). London: Simon Pooley.

720

721

722

723

724

725

726

727

728

729

730

731

732

733

734

735

736

737

738

Rafajlović, M., Eriksson, A., Rimark, A., Hintz-Saltin, S., Charrier, G., Panova, M., ... Mehlig, B. (2013). The effect of multiple paternity on genetic diversity of small populations during and after colonisation. PLoS ONE, 8, e75587.

Rebêlo, G. H., \& Magnusson, W. E. (1983). An analysis of the effect of hunting on Caiman crocodilus and Melanosuchus niger based on the sizes of confiscated skins. Biological Conservation, 26, 95-104.

Reese, A. M. (1923). The habitat of the Crocodilia of British Guiana. Ecology, 4, 141-146.

Roberto, I. J., Bittencourt, P. S., Muniz, F. L., Hernández-Rangel, S. M., Nóbrega, Y. C., Ávila, R. W., ... Hrbek, T. (2020). Unexpected but unsurprising lineage diversity within the most widespread Neotropical crocodilian genus Caiman (Crocodylia, Alligatoridae). Systematics and Biodiversity, 1-19.

Rodriguez-Cordero, A. L., Balaguera-Reina, S. A., \& Densmore III, L. D. (2019). Regional conservation priorities for crocodylians in Bolivia. Journal for Nature Conservation, $52,125753$.

Sill, W. D. (1968). The zoogeography of the Crocodilia. Copeia, 1968, 76-88.

Smith, N. J. H. (1981). Caimans, capybaras, otters, manatees, and man in Amazônia. Biological Conservation, 19, 177-187.

Somaweera, R., Brien, M., \& Shine, R. (2013). The role of predation in shaping crocodilian natural history. Herpetological Monographs, 27, 23-51. 


\section{[Type text]}

739 Souza-Filho, J. P., Souza, R. G., Hsiou, A. S., Riff, D., Guilherme, E., Negri, F. R., \& Cidade, G. M. (2018). A new caimanine (Crocodylia, Alligatoroidea) species from the Solimões Formation of Brazil and the phylogeny of Caimaninae. Journal of Vertebrate Paleontology, 38, e1528450.

743 Tavares de Freitas, C., Macedo Lopes, P. F., Campos-Silva, J. V., Noble, M. M., Dyball, R., \& Peres, C. A. (2019). Co-management of culturally important species: A tool to promote biodiversity conservation and human well-being. People and Nature.

746 Thorbjarnarson, J. (1994). Comments on the Ecuadorian proposal for the transfer of populations of Melanosuchus niger to Appendix II under the Ranching criteria. Prepared for the IUCN/SSC CSG Steering Committee Meeting.

Thorbjarnarson, J., \& Da Silveira, R. (2000). Secrets of the flooded forest. Natural History, 109, $70-79$.

Thorbjarnarson, J., \& Velasco, A. (1999). Economic incentives for management of 752 Venezuelan caiman. Conservation Biology, 13, 397-406.

Thorbjarnarson, J. B. (1992). Crocodiles: an action plan for their conservation Gland, Switzerland: UICN - The World Conservation Union.

755 Thorbjarnarson, J. B. (1996). Reproductive characteristics of the order Crocodylia. 756 Herpetologica, 52, 8-24.

757 Thorbjarnarson, J. B. (1999). Crocodile tears and skins: international trade, economic 758 constraints, and limits to the sustainable use of crocodilians. Conservation Biology,

760 Torralvo, K., Botero-Arias, R., \& Magnusson, W. E. (2017). Temporal variation in black761 caiman-nest predation in varzea of central Brazilian amazonia. PloS ONE, 12, e0183476. 


\section{[Type text]}

763 Tosun, D. D. (2013). Crocodile farming and its present state in global aquaculture. Journal of

764

765

766

767

768

769

770

771

772

773

774

775

776

777

778

779

780

781

782

783

784

785

786

787 FisheriesSciences.com, 7, 43-57.

van Uhm, D. P., \& Nijman, R. C. C. (2020). The convergence of environmental crime with other serious crimes: Subtypes within the environmental crime continuum. European Journal of Criminology, 0, 1477370820904585.

van Vliet, N., Mesa, M. P. Q., Cruz-Antia, D., de Aquino, L. J. N., Moreno, J., \& Nasi, R. (2014). The uncovered volumes of bushmeat commercialized in the Amazonian trifrontier between Colombia, Peru \& Brazil. Ethnobiology and Conservation, 3.

Vanzolini, P. E., \& Gomes, N. (1979). Notes on the ecology and growth of Amazonian caimans (Crocodylia, Alligatoridae). Papéis Avulsos de Zoologia, 32, 205-216.

Vasconcelos, W. R., Hrbek, T., Da Silveira, R., Thoisy, B. d., Marioni, B., \& Farias, I. P. (2006). Population genetic analysis of Caiman crocodilus (Linnaeus, 1758) from South America. Genetics and Molecular Biology, 29, 220-230.

Velasco, A. (2008). Crocodile management, conservation and sustainable use in Latin America. Crocodiles. Proceedings of the 19th Working Meeting of the Crocodile Specialist Group. (pp. 72-88), Gland, Switzerland and Cambridge UK: IUCN - The World Conservation Union.

Venticinque, E., Forsberg, B., Barthem, R., Petry, P., Hess, L., Mercado, A., ... Goulding, M. (2016). An explicit GIS-based river basin framework for aquatic ecosystem conservation in the Amazon. Earth System Science Data, 8, 651-661.

Verdade, L. M. (2004). A exploração da fauna silvestre no Brasil: jacarés, sistemas e recursos humanos. Biota Neotropica, 4, 1-12.

Villamarín, F., Jardine, T. D., Bunn, S. E., Marioni, B., \& Magnusson, W. E. (2017). Opportunistic top predators partition food resources in a tropical freshwater ecosystem. Freshwater Biology, 62, 1389-1400. 


\section{[Type text]}

788 Villamarín, F., Marioni, B., Thorbjarnarson, J. B., Nelson, B. W., Botero-Arias, R., \&

789

790

791

792

793

794

795

796

797

798

799

800

801

802

803

804

805

806

807

808

809

810

\section{6}

\section{7} Magnusson, W. E. (2011). Conservation and management implications of nest-site selection of the sympatric crocodilians Melanosuchus niger and Caiman crocodilus in Central Amazonia, Brazil. Biological Conservation, 144, 913-919.

Villamarín, F., \& Suárez, E. (2007). Nesting of the black caiman (Melanosuchus niger) in Northeastern Ecuador. Journal of Herpetology, 41, 164-168.

Webb, G. J., Brien, M., Manolis, C., \& Medrano-Bitar, S. (2012). Predicting total lengths of spectacled caiman (Caiman crocodilus) from skin measurements: a tool for managing the skin trade. Herpetological Conservation and Biology, 7, 16-26.

Webb, G. J. W., \& Jenkins, R. W. G. (2016). Concerns about the production and trade in Brown caimans (Caiman crocodilus fuscus) from Colombia. Information document SC66 Inf. 20 submitted by European Union at 66th meeting of the CITES Standing Committee, 11, 19.

Willi, Y., \& Hoffmann, A. A. (2009). Demographic factors and genetic variation influence population persistence under environmental change. Journal of Evolutionary Biology, $22,124-133$.

Yasui, Y. (1998). The genetic benefits' of female multiple mating reconsidered. Trends in Ecology \& Evolution, 13, 246-250. 
[Type text]

\section{Tables}

813 Table 1: Current conservation status of the four caiman species occurring in the Amazon

814 basin according to IUCN Red List (https://www.iucnredlist.org) and CITES Appendix

815 (https://www.cites.org), management actions, country, and main product issued from

816 management action. $\mathrm{LC}=$ Least Concern, $\mathrm{LR}=$ Low Risk.

817

\begin{tabular}{|c|c|c|c|c|c|c|}
\hline Species Name & Common Name & IUCN & CITES & $\begin{array}{l}\text { Management } \\
\text { type }\end{array}$ & Countries & $\begin{array}{c}\text { Main } \\
\text { product }\end{array}$ \\
\hline Caiman crocodilus & Spectacled Caiman & $\mathrm{LC}$ & II & $\begin{array}{l}\text { Harvesting, } \\
\text { ranching and } \\
\text { captive breeding }\end{array}$ & $\begin{array}{l}\text { Venezuela, } \\
\text { Colombia }^{1}\end{array}$ & $\begin{array}{c}\text { Skin and } \\
\text { meat }\end{array}$ \\
\hline Melanosuchus niger & Black Caiman & LR & $\mathrm{I}^{2}$ & Harvesting & Brazil & $\begin{array}{c}\text { Skin and } \\
\text { meat }\end{array}$ \\
\hline $\begin{array}{l}\text { Paleosuchus } \\
\text { palpebrosus }\end{array}$ & $\begin{array}{l}\text { Cuvier's Smooth-fronted } \\
\text { Caiman }\end{array}$ & $\mathrm{LC}$ & II & - & & \\
\hline $\begin{array}{l}\text { Paleosuchus } \\
\text { trigonatus }\end{array}$ & $\begin{array}{l}\text { Schneider's Smooth- } \\
\text { fronted Caiman }\end{array}$ & $\mathrm{LC}$ & II & - & & \\
\hline
\end{tabular}

$818{ }^{1}$ None of management actions in these countries are carried out in Amazon basin

$819{ }^{2}$ Except for the populations of Brazil and Ecuador, included in Appendix II, subject to a zero annual export 820 quota until an annual export quota is approved

821

\section{Figure legends:}

823 Figure 1. The four crocodilians species encountered in Amazon basin: A) Black caiman

824 (Melanosuchus niger), B) Spectacled caiman (Caiman crocodilus), C) Schneider's Dwarf 825 caiman (Paleosuchus trigonatus) and D) Cuvier's Dwarf caiman (Paleosuchus palpebrosus). 